\title{
О СВЯЗИ МЕЖДУ СОВРЕМЕННЫМИ ДВИЖЕНИЯМИ ЗЕМНОИ КОРЫ И ЭРОЗИОННО-АККУМУЛЯТИВНОЙ ДЕЯТЕЛЬНОСТЬЮ РЕК ЭСТОНИИ
}

На территории Эстонии давно установлено поднятие земной корь, происходившее в течение поздне- и послеледникового периодов и продолжающееся в настоящее-время.

Как явствует из работ Г. Желнина $[3-5,32-34]$, в пределах Эстонии интенсивность современных движений уменьшается с северо-запада к юго-востоку. В результате этого поднятия происходит общее наклонение земной поверхности в юго-восточном направлении. В работах Г. Желнина $[4,5,33]$ приведены также данные, указывающие, что современные тектонические движения происходят неравномерно. Это находит свое четкое выражение в сгущении изобаз на схеме современных тектонических движений. Таким образом, из результатов повторной нивелировки вытекает, что при изучении современных тектонических двнжений в разных частях Эстонии, по-видимому, целесообразно различать общее наклонное тектоническое поднятие и дифференциальные тектонические движения, которые происходят на фоне общего поднятия. В связи с этим небезынтересно сравнить результаты повторной нивелировки с данными, полученными геолого-геоморфологическими методами. Для этого мы используем данные изучения долин, в частности, продольных профилей рек. При изучении последних были выделены аномальные падения рек, которые представлены на схематической карте падений рек (см. рис. 6). Аномальные падения определены по методике, разработанной Л. Сетунской [19], Ю. Мещеряковым и А. Филькиным [8] и Ю. Мещеряковым [9].

Продольные профили рек в разных частях территории Эстонии различны $[14,15,26,35,36]$. К. Орвику $[14,15,27]$ объясняет это прежде всего различной интенсивностью современных тектонических движений и отчасти характером рельефа коренных пород.

Продольные профили рек Северной Эстонии имеют в общих чертах выпуклую форму. Так как для равнинных рек умеренного пояса характерен вогнутый продольный профиль, то продольные профили рек Сeверной Эстонии являются аномальными, а их интенсивное развитие и выработка продолжается и в настоящее время. Продольным профилям рек Северной Эстонии свойственно относительно небольшое падение в верхнем и среднем течении и аномально крутое - в нижнем течении. Е низовьях рек выделяется много аномальных участков (см. рис. 6) с большими абсолютными величинами падения, достигающими до $700-$ $800 \mathrm{~cm} / \kappa м$. Здесь аномальные участки образуют полосу, протягивающуюся вдоль глинта и побережья Финского залива с запада на восток. В среднем и верхнем течении аномальных участков меньше. Как выяснилось, общая форма профилей рек в большой мере отражает рельеф коренных пород, в частности крупные формы последнего (СевероЭстонский глинт и др.). Образование аномальных участков в верхнемв 


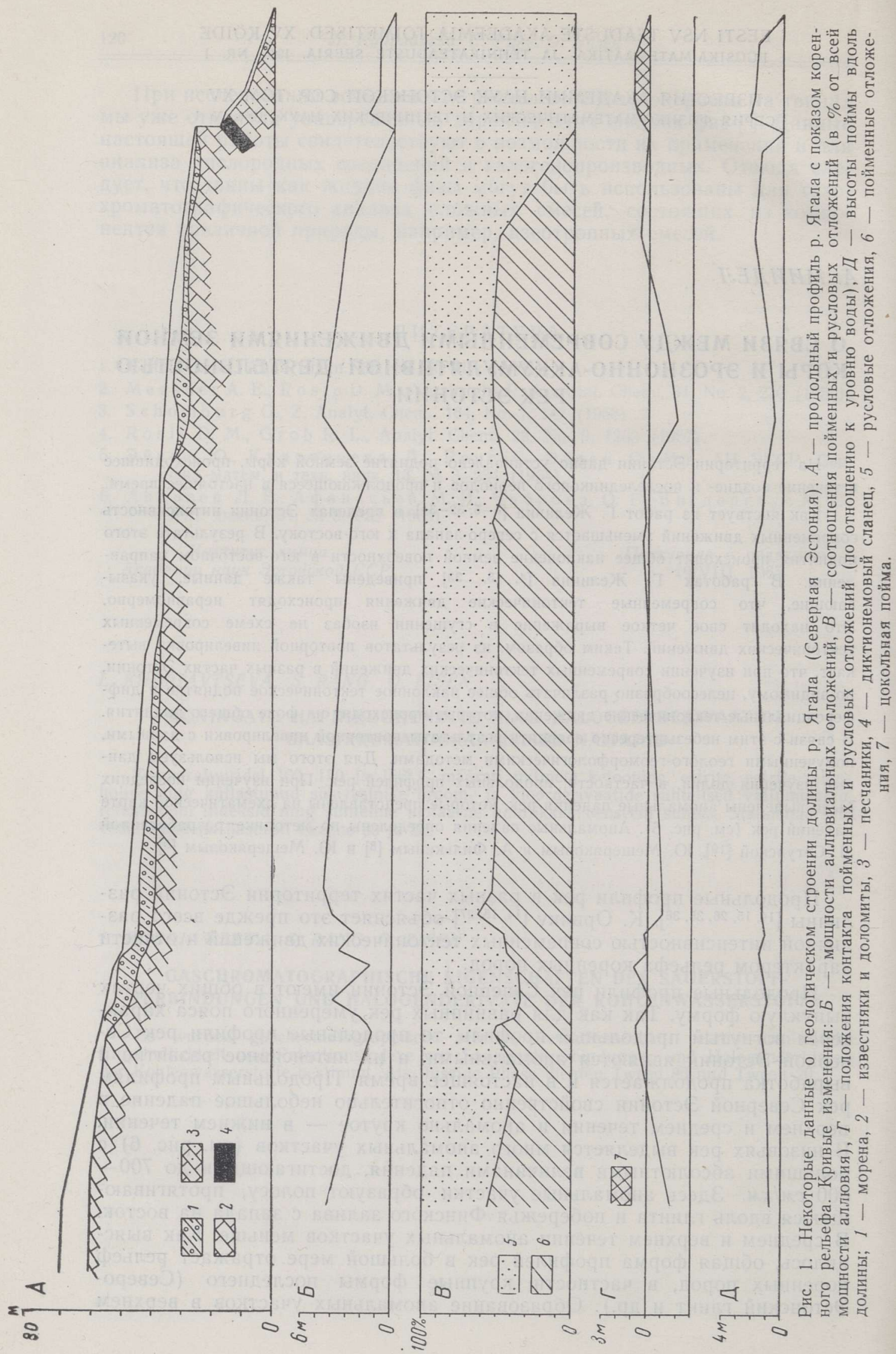




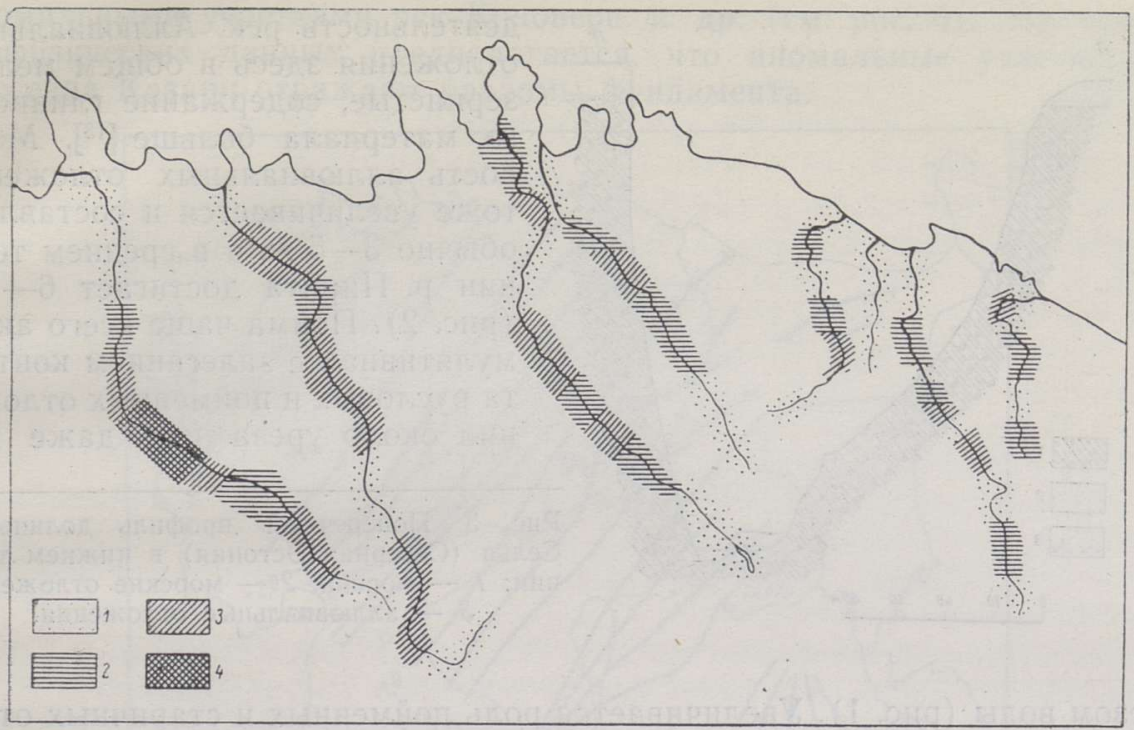

Рис. 2. Схема мощности аллювнальных отложений в долинах Северной Эстонии. Мощность аллювиальных отложений: 1 - до 2 м, 2 - от 2 до 3 м, 3 от 3 до $5 \mathrm{M}, 4->5 \mathrm{~m}$.

и среднем течении во многом обусловлено либо уступами рельефа коренных пород, либо прорывом реками краевых образований последнего оледенения, где обычно обнажаются более устойчивые к эрозии отложения [ $\left.{ }^{11}\right]$. Наряду с влиянием древнего рельефа в нижнем течении рек Северной Эстонии проявляется большая роль неотектонических движений. Здесь наличие аномальных участков в рыхлых четвертичных отложениях и в слабоцементированных песчаниках ордовика и кембрия необходимо рассматривать как результат совместного действия древнего рельефа и общего поднятия земной коры.

О продолжающемся поднятии земной коры в северной части республики свидетельствуют и многие другие черты геологического строения долин. По-данным А. Мийдела и А. Раукаса $\left[{ }^{13}\right]$, среди аллювиальных отложений низовьев североэстонских рек преобладают грубозернистый песчаный и гравийный аллювий. Для низовьев рек Северной Эстонии в общем характерно преобладание русловых отложений над пойменными (рис. 1) при ограниченном распространении старичных отложений. В то же время контакт русловых и пойменных отложений в большинстве случаев расположен высоко над урезом воды. Пойма часто является цокольной (рис. 1), и в ее строении участвуют, кроме аллювиальных, разные породы кембрия и ордовика или же различные четвертичные отложения (морена, ленточные глины и т. д.). Мощность аллювиальных отложений незначительна, обычно не превышает $2,0-2,5$ м и только изредка достигает $4-5 \mu$ (рис. 2). В низовьях рек глубина долин достигает местами $30-35$ м, а в верхнем и среднем течении в то же время обычно не превышает 5-7 м. Долины узкие, крутосклонные, в поперечном профиле часто $V$-образные (рис. 3 ). Таким образом, приведенные данные подтверждают мнение К. Орвику $\left[{ }^{14,15}\right]$ и Ю. Мещерякова [10] о том, что интенсивность врезывания рек Северной Эстонии обусловлена в основном современным поднятием земной коры.

В то же время в верхнем и среднем течении рек труднее заметить прямое влияние современного поднятия на эрозионно-аккумулятивную 


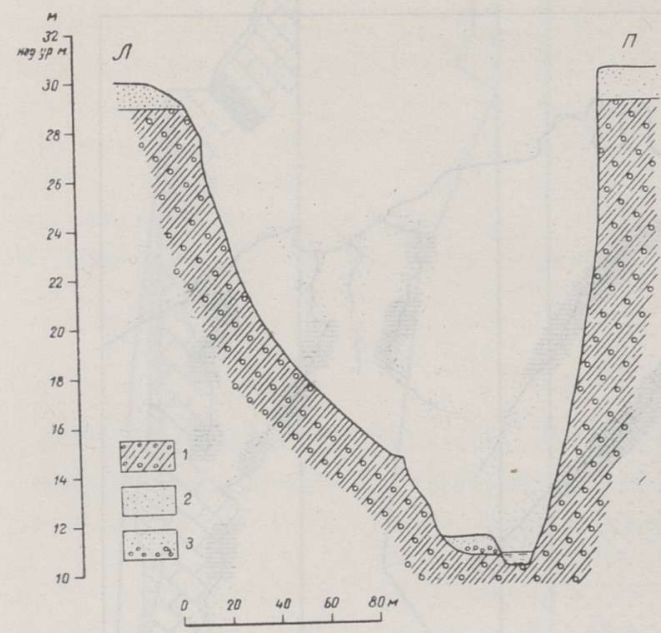

деятельность рек. Аллювиальные отложения здесь в общем мелкозернистые, содержание глинистого материала больше [13]. Мощность аллювиальных отложений тоже увеличивается и составляет обычно 3-5 м, а в среднем течении р. Пирита достигает $6-7 \mathrm{~m}$ (рис. 2). Пойма чаще всего аккумулятивная с залеганием контакта русловых и пойменных отложений около уреза или даже под

Рис. 3. Поперечный профиль долины $\mathrm{p}$ Селья (Северная Эстония) в нижнем течении: 1 - морена; 2 - морские отложения; 3 - аллювиальные отложения.

урезом воды (рис. 1). Увеличивается роль пойменных и старичных отложений. Более или менее резкие изменения в строении поймы и характера аллювия здесь приуроуены только к аномальным участкам.

Приведенные особенности долин среднего и верхнего течения рек Северной Эстонии можно объяснить, по-видимому, следующими обстоятельствами. Распространение влияния понижения общего базиса зрозия как прямого результата. поднятия земной коры вверх по долинам затруднительно из-за наличия крупного местного базиса эрозии в виде Северо-Эстонского глинта. Спуск рек с уступа глинта часто сопровождается водопадами высотой до 8 м. Нет сомнения, что регрессивное рас. пространение эрозионно-аккумулятивных процессов от устья вверх по течению перед глинтом задерживается. Этому способствует геологическое строение глинта (в верхней части он состоит из твердых известняков), из-за чего врезание рек вверх по течению от линии глинта незначительное. Как явствует из схемы изобаз современных движений, составленной Г. Желниным (рис. 4), некоторое наклонение земной поверхности происходит в юго-восточном направлении, что вместе с моноклинальным залеганием и слабым падением коренных пород в южном направлении, а также наличием местных базисов эрозии, возможно, обусловливает подпор стока вод в верхнем и среднем течении рек Северной خстонии. Таким образом, особенности строения долин Северной Эстонии на более удаленных об общего базиса эрозии участках объясняются переплетением влияния многих факторов.

В среднем течении рек бассейна Казари (Западная Эстония) намечается полоса аномальных участков, образующая полукруг, повернутый своей вогнутой стороной на запад (см. рис. 6). По рельефу коренных пород реки бассейна Казари в своем нижнем течении располагаются в понижении. Аномальные участки этих рек выделяются на пологом склоне коренного рельефа, где часто обнажаются силурийские карбонатные породы. Интересно отметить, что по данным Э. Побуля $\left[{ }^{17}\right]$ в среднем и нижнем течении рек бассейна Қазари в кристаллическом фундаменте имеется ряд разломов, которые окружают бассейн Казари с севера, юга и запада. Некоторые из этих разломов пересекаются аномальными участками, а один разлом меридиального простирания находится вблизи устья р. Казари. Аэромагнитные данные тоже указывают на наличие тектонических нарушений в фундаменте, пересекающихся 
аномальными участками рек Коновере и др. (см. рис. 6). На основе геофизических данных предполагается, что аномальные участки рек бассейна Казари отражают разломы фундамента.

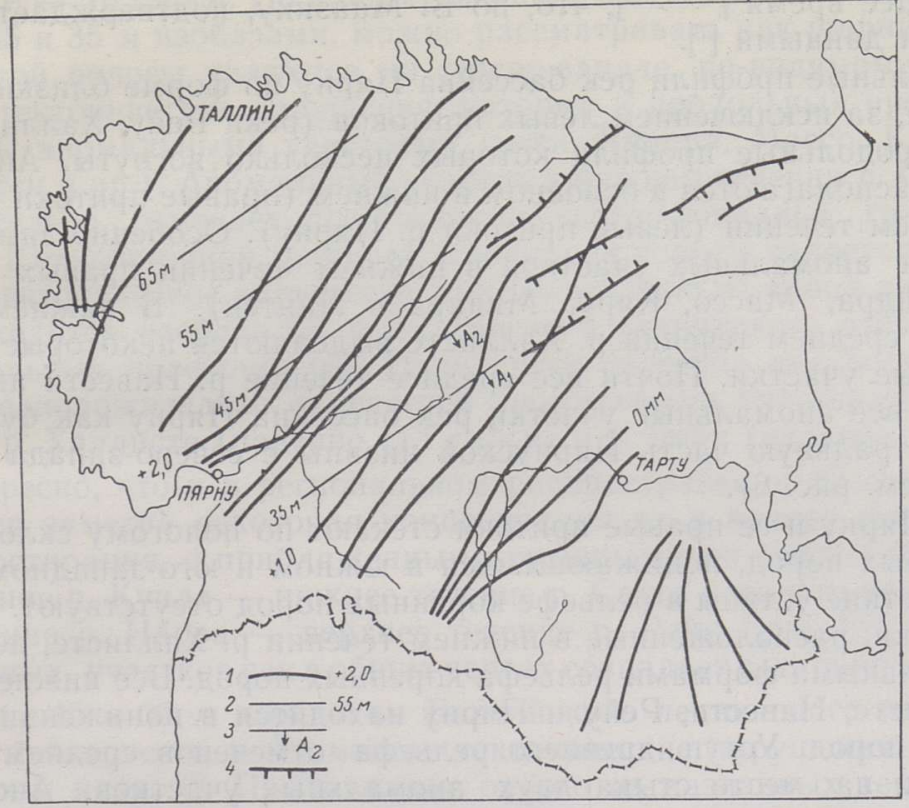

Рис. 4. Схема изобаз современных тектонических движений Эстонии: 1 - изобазы современных движений земной коры через 0,2 мм (по [5]);2 - изобазы Балтийского ледникового озера $\mathrm{B}_{3}$ (по К. Пярна); 3 - места резкого изменения положения уровней крупных приледниковых озер $\mathrm{A}_{1}$ и $\mathrm{A}_{2}$ (при азимуте $326^{\circ}$ ), стрелкой указана опущенная часть уровней; 4 - тектонические нарушения, установленные геологической съемкой.

Интересной особенностью рассматриваемого района является северное направление и сгущение изобаз современного поднятия (рис. 4), выявленные Г. Желниным [5] повторной нивелировкой. Имея в виду приведенные данные, не исключена возможность, что северное направление и сгущение изобаз современного поднятия в нижнем течении р. Қазари связано с дифференциальными тектоническими движениями, в частности, если принимать во внимание исторические данные о сейсмичности западной части ЭССР $\left[{ }^{24}\right]$ и линейное расположение эпицентров землетрясений на восточном берегу Ботнического залива и на берегу Курземского полуострова [28].

Қ сожалению, геологическое строение долин и окрестностей бассейна Казари изучено слишком слабо для того, чтобы мы могли достаточно обосновать наши выводы. Тем не менее нам кажется, что влияние общего поднятия земной коры здесь проявляется слаб́. По К. Орвику $[14,15]$ это связано с тем, что общее тектоническое поднятие вдоль всего продольного профиля рек здесь более или менее одинаковое, а рельеф довольно пологий.

С точки зрения влияния современных движений земной коры на ха . рактер деятельности рек особый интерес представляет бассейн р. Пярну (Западная Эстония). Это связано с тем, что здесь проходит предполагаемая позднеледниковая шарнирная линия, выявленная Қ. Пярна $\left.{ }^{18}\right]$ при изучении позднеледниковых водоемов. Здесь же предполагается 
продолжение зоны тектонических нарушений, выявленной в СевероВосточной Эстонии [14]. В то же время данные повторной нивелировки указывают на продолжение тектонических движений на этой линии и в настоящее время $[5,20,33]$, что, по В. Маазику, подтверждается геофизическими данными [7].

Продольные профили рек бассейна Пярну по форме близки к прямолинейным, за исключением левых притоков (реки Рейу, Халлисте, Кыпу и др.), продольные профили которых несколько вогнуты. Аномальные участки располагаются в основном в нижнем (правые притоки р. Пярну) и в среднем течении (левые притоки р. Пярну). Особенно заметна концентрация аномальных участков в нижнем течении правых притоков (реки Вяндра, Массо, Кяру, Мядара и Линтси). В нижнем течених p. Рейу и среднем течении р. Халлисте выделяются некоторые короткие аномальные участки. Почти все среднее течение р. Навести аномально. В общем, все аномальные участки рек бассейна Пярну как будто окружают центральную часть Пярнуской низины с северо-запада и с юговостока (см. рис. 6).

Река Пярну и ее правые притоки стекают по пологому склону рельефа коренных пород, понижающемуся в южном и юго-западном направлениях. Четкие уступы в рельефе коренных пород отсутствуют. Аномальные участки, расположенные в нижнем течении р. Халлисте, не связаны положительными формами рельефа коренных пород. Все нижнее течение рек Халлисте, Навести, Рейу и Пярну находится в понижении рельефа коренных пород. Уступ древнего рельефа отмечен в среднем течении р. Навести на месте стыка двух аномальных участков. Аномальные участки в верхнем течении рек Кыпу и Халлисте, а также на р. Раудна приурочены к склонам Сакалаской возвышенности (см. рис. 6).

В пределах аномальных участков рек Кяру, Вяндра и Пярну известны выходы коренных пород. Последние обнажаются также на аномальных участках рек Навести, Раудна, Қыпу и в среднем течении р. Халлисте.

По данным аэромагнитной съемки, в фундаменте района Вяндра выделяют поднятие, которое на юго-востоке ограничивается Вяндраской впадиной. Обе структуры вместе образуют, по некоторым авторам, флексуру с приподнятым северо-западным крылом. Ими отмечены здесь также тектонические нарушения приблизительно северо-восточного простирания (см. рис. 6). Интересно, что на стыке этих структур располагаются аномальные участки на реках Вяндра, Массо, Кяру, Мядара и др. Согласно аэромагнитной съемке, между устьями рек Вяндра и Пранди вдоль долины р. Пярну простирается тектоническое нарушение северо-восточного направления, являющееся, по-видимому, продолжением тектонических нарушений, установленных Э. Побулем * между Ярва-Яани и Тамсалу, несколько северо-западнее Азериского тектонического нарушения (см. рис. 6). Судя по приведенным данным, выявляется связь между геологическим строением фундамента и расположением аномальных участков рек Вяндра, Кяру, Мядара, Линтси и др. Названные аномальные участки и тектонические нарушения фундамента, возможно, маркируют северо-западную границу так наз. шарнирной полосы. Некоторым доказательством такого предположения служат следующие факты. По данным К. Пярна $\left[{ }^{18}\right]$, градиенты опорного уровня Балтийского ледникового озера $\left(\mathrm{B}_{3}\right)$ имеют следующие

* E. Pobul, Seos magnetiliste struktuuride ja territooriumi geoloogilise ehituse vahel Tanısalu ja Võhma-Pilistvere magnetiliste anomaaliate piirkondades Eesti NSV keskosas, Рукопись, Институт геологии АН ӘССР, Таллин, 1963. 
величины: между изобазами 65 и 55 м - 45 cм/км, между изобазами 55 и 45 м - $38 \mathrm{~cm} / \kappa м$, между изобазами 45 и 35 м $30 \mathrm{~cm} / \kappa м$, а от 35 -метровой изобазы к юго-востоку примерно до границы Латвийской и Эстонской ССР - $18 \mathrm{~cm} / \kappa м$. По нашему мнению, всю полосу, по меньшей мере, между 45 и 35 м изобазами, можно рассматривать как шарнирную. Границей этой полосы являются на северо-западе, по-видимому, выненазванные тектонические нарушения, которые в продольных профилях рек отмечены аномальными участками (реки Вяндра, Массо, Кяру, Мядара, Линтси и др.). Аномальный участок в нижнем течении р. Сауга предположительно отмечает продолжение северо-западной границы этой полосы. Юго-восточной границей шарнирной полосы является Вийвиконнаское тектоническое нарушение, приблизительно на одной линии с которым находится изобаза 35 м Балтийского ледникового озера (рис. 4). В продольных профилях рек Пярнуского бассейна юго-восточная граница предположительно отмечается аномальными участками в среднем течении р. Халлисте (падение 113 см/км) и р. Рейу (падение 165 см/км).

Интересно, что и в региональном распространении аномальных участков рек заметна некоторая концентрация их в полосу северо-востопного простирания, с приближенными границами на северо-западе: нижнее течение р. Кунда - нижнее течение р. Сауга и на юго-востоке: верхнее течение р. Нарва - верхнее течение р. Рейу (рис. 6). Эта полоса аномальных участков рек в общих чертах совпадает с шарнирной полосой.

Между 45 и 35 м изобазами Балтийского ледникового озера размещаются и Азериское и Ахтмеское тектонические нарушения, описанные Р. Вахером и др. $\left[{ }^{2}\right]$. Продолжение одного из названных тектонических нарушений в бассейне р. Пярну можно предполагать через аномальный участок р. Навести (падение 129 см/км), вдоль р. Навести до устья р. Халлисте, вдоль р. Халлисте от устья до поворота реки к юго-востоку, а дальше через аномальный участок р. Рейу (падение $35 \mathrm{~cm} / \kappa м$ ). Основанием такого предположения является, кроме аномального падения рек Рейу и Навести, тот факт, что р. Халлисте в нижнем течении, начиная от р. Рийза до впадения в р. Навести, течет навстречу течению последней $\left[{ }^{12}\right]$. Известно также, что нижние течения рек Халлисте и Қыпу часто подвергаются наводнениям. В то же время на правом берегу p. Навести большие наводнения не известны. Левее р. Навести находится также болото Куресоо. Через аномальные участки р. Навести, очевидно, продолжаются также тектонические нарушения в фундаменте, обнаруженные Э. Побулем * в окрестности Выхма.

Как видно из схемы изобаз (рис. 4), и в настоящее время примерно в полосе между изобазами Балтийского ледникового озера ( $\left.\mathrm{B}_{3}\right) 45$ и 35 м градиент скорости поднятия изменяется. В то же время большинство участков с дифференциальными движениями, обнаруженными повторной нивелировкой, концентрируется в эту полосу особенно вблизи тектонических нарушений, выявленных либо геофизическими, либо геологическими методами. Наличие в настоящее время тектонически активной шарнирной полосы в средней части Әстонии проявляется также на схеме градиентов скорости вертикальных движений земной поверхности, составленной Л. Былинской и Ю. Мещеряковым [1]. Совпадение полосы аномальных участков рек с шарнирной полосой указывает на зависимость характера продольных профилей рек от современных тектонических движений, происходящих в полосе и имеющих, вероятно, дифференциально-блоковый характер.

* См. прим. на стр. 126. 


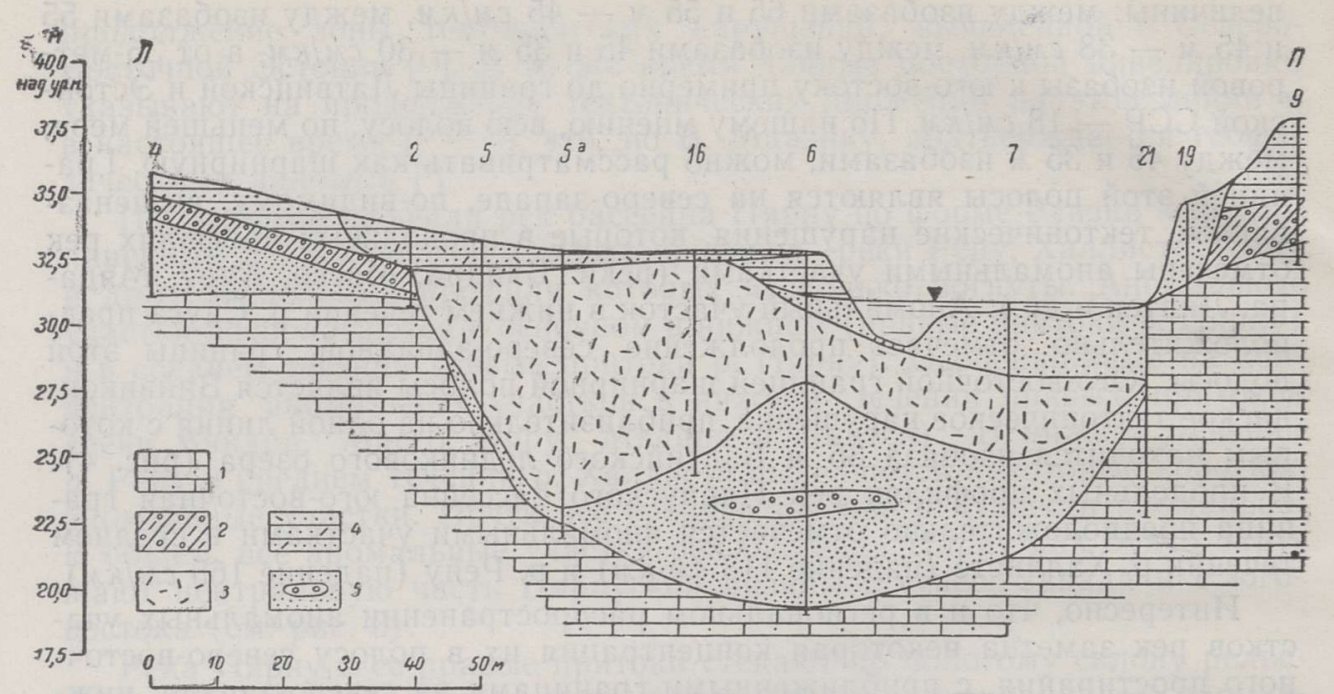

Рис. 5. Поперечный профиль долины р. Выханду (Южная Эстония) в нижнем течении: 1 - девонские песчаники; 2 - морена; 3 - торф; 4 - аллювиальные супеси; 5 аллювиальные пески с гравием.

Әта зона, по-видимому, представляет собой часть большой внешней флексуры М. Саурамо [30, 31], продолжающейся, по В. Гуделису [21], на Курземском полуострове. Хотя в последнее время концепция флексур M. Саурамо оспаривается $Э$. Нююпя [23], геологические данные на территории Әстонии говорят в пользу существования древних тектонических швов, активизировавшихся в позднеледниковое время.

По Р. Вахеру и др. $\left.{ }^{2}\right]$, тектонические нарушения северо-восточного простирания (видимо, глубинного заложения) оформились в течение завершающей фазы каледонского орогенеза. Были ли они активными во время длительного континентального периода в мезо- и кайнозое - не известно. По К. Орвику $\left[{ }^{14}\right]$, они оживились в позднеледниковое время. Добавим еще, что при увязке уровней крупных местных приледниковых озер $\left(A_{1}\right.$ и $\left.A_{2}\right)$, выявленных на северо-западном склоне возвышенности Пандивере, с уровнями, установленными на склонах возвышенности Сакала, на западном побережье озера Пейпси и около Тарту, К. Пярна [18] был вынужден выбрать новый азимут максимального изменения интенсивности поднятия $\left(335 \pm 5^{\circ}\right)$, при котором уровни $A_{1}$ и $A_{2}$ образовали единые беспрерывные уровни. При азимуте $326^{\circ}$, которым К. Пярна пользуется при увязке более молодых древних береговых линий, отдельные отрезки уровней $A_{1}$ и $A_{2}$ оказались на разных высотах. ных К. Пярна следует, что на линии $35 \mu$ изобазы $\mathrm{B}_{3}$, т. е. на продолжении Вийвиконнаского тектонического нарушения, уровень $A_{1}$ опущен примерно на $7-8$ м (рис. 4), а около г. Тарту этот уровень почти горизонтален. Уровень $\mathrm{A}_{2}$ тоже опущен около 10 м приблизительно на линии Ахтмеского тектонического нарушения (рис. 4). По нашему мнению, эти факты являются еще одним доказательством оживления древнего тектонического шва в позднеледниковое время.

Основываясь на приведенных данных о геологическом строении бас-

* К. Пя нн а, О геологии Балтийского приледникового озера и крупных местных приледниковых озер на территорин Эстонии, Диссертация, Центр. библ. АН ЭССР, Таллин, 1962. 


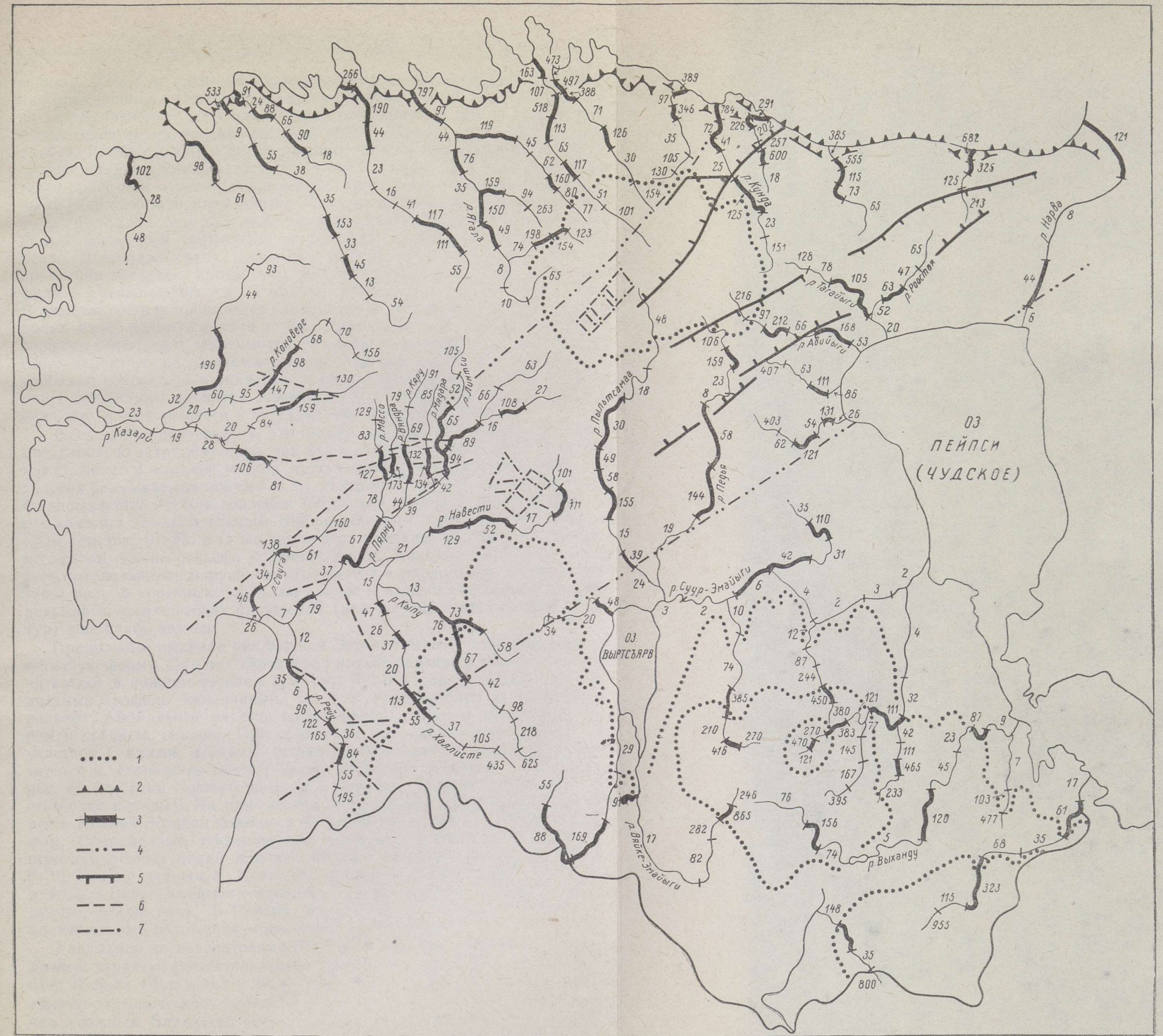

Рис. 6. Схема падений рек Эстонии: 1 - контуры возвышенностей древнего рельефа; 2 - Северо-Эстонский глинт; 3 - аномальные участки (цифрами обозначены величины падения рек в см/км); 4 - приближенные границы зоны аномальных падений северовосточного направления; 5 - тектонические нарушения, установленные геологической съемкой; 6 - тектонические нарушения в фундаменте, установленные аэромагнитной съемкой; 7 - тектонические нарушения в фундаменте (по данным Э. Побуля). 
сейна р. Пярну, а также на характере продольных профилей рек, влияние современных дифференциальных движений земной коры на эрозионно-аккумулятивную деятельность рек этого бассейна можно представить в виде следующей предварительной схемы. Правые притоки р. Пярну (Сауга, Вяндра и др.) в своем нижнем течении врезаются в северо-западный край поднимающегося блока земной коры. Для этих рек характерен более или менее прямолинейный продольный профиль с аномальными участками в нижнем течении. В то же время левые притоки р. Пярну (Рейу, Халлисте и др.) подвержены влиянию поднятия земной коры, увеличивающегося (возможно, ступенчато) в северо-западном направлении. Благодаря этому эрозионная деятельность этих рек в этом направлении затухает. Кроме того, для них характерен продольный профиль с уменьшающимися, в общем, уклонами в направлении устья. В нижнем течении происходят наводнения и развиваются заболачивания долин из-за подпруживания стока. Деятельность р. Пярну протекает, главным образом, в зависимости от древнего рельефа и от литологического характера размываемых пород. Так как река течет параллельно изобазам современных движений и вдоль шарнирной полосы, то влияние современного поднятия земной коры, по-видимому, имеет меньшее значение, выражающееся в ее удлинении в нижнем течении.

Здесь нужно подчеркнуть, что оценка влияния тектонических движений довольно затруднительна, так как в наших условиях на этот фактор накладывается влияние многих других факторов (древний рельеф, литология размываемых пород и т. д.). Например, на р. Пыльтсамаа имеется аномальный участок (падения 155 см/км), который, по-видимому, пересекается с предполагаемым Вийвиконнаским тектоническим нарушением (см. рис. 6). Но в то же время этот аномальный участок находится на крутом склоне рельефа коренных пород. Конечно, можно предполагать, что названное нарушение отражается в продольном профиле реки через рельеф коренных пород, но вопрос о взаимоотношениях древнегс рельефа и тектонических нарушений (или вообще тектонических структур) еще слабо изучен.

Продольные профили рек Южной Эстонии имеют четко выраженную вогнутую форму. Для них характерно крутое падение в верхнем и незначительное в нижнем течении (см. рис. 6). В верхнем течении рек продольный профиль изменчивый, так как приспособлен к ледниковому рельефу. Аномальные участки расположены, главным образом, в верхнем и среднем течении. При сравнении местоположений аномальных участков с картой древнего рельефа обнаруживается приуроченность первых к склоновым частям возвышенностей древнего рельефа (см. рис. 6), где реки глубоко врезаны в коренные породы (девонские кластические породы). На наш взгляд, образование аномальных участков рек в Южной Эстонии связано в большинстве случаев с древним рельефом. Современные тектонические движения хорошо проявляются в строении речных долин Южной Эстонии лишь в их нижнем течении $\left[{ }^{6,}{ }^{14}\right]$. Так, по данным К. Каяка [6], мощность аллювиальных отложений в устье р. Вяйке-Эмайыги составляет 15 м (в основном пойменные и старичные отложения). В Ряпина, близ устья р. Выханду, установлены аллювиальные отложения мощностью 13,5 м (рис. 5).

Уже давно исследователями $[14,16,25,29]$ обращено внимание на различный характер неотектонических движений в северной и южной частях озер Пейпси (Чудского) и Выртсъярв. Оказывается, что интенсивность сбщего тектонического поднятия в северных частях этих озер больше, чем в южных. Благодаря этому происходит перекос этих озер в южном направлении. Свидетельством повышения базиса эрозии являются боль-

9 ENSV TA Toimetised F-1 66. 
шая мощность аллювия и незначительное падение в нижнем течении рек $\left[{ }^{14}, 15\right]$. Большую роль этого процесса в развитии долин Южной Эстонии подчеркивают также Э. Ханг и др. [22].

Продольные профили рек, впадающих в озеро Пейпси (Чудское) с севера, близки к прямолинейным. Аномальные участки этих рек входят в зону аномальных участков северо-восточного простирания. По предварительным данным, они не связаны с рельефом коренных пород. Возможно, что в некоторых случаях происхождение аномальных участков обусловлено тем, что эрозии подвергается морена, обычно содержащая много валунов (реки Омеду, Куллавере). На реках Авийыги, Тагайыги и Роостоя образование аномальных участков связано, вероятно, с Вийвиконнаским тектоническим нарушением (в частности, если учесть данные повторной нивелировки $[5,20])$. По этим данным на трассе Муствээ-Иыхви участки резких относительных смещений реперов находятся приблизительно над Ахтмеским и Вийвиконнаским тектоническими нарушениями. По имеющимся данным, мощность аллювия рек, впадающих в северную часть озера Пейпси (Чудского), составляет в среднем $3-4 \boldsymbol{\mu}$. Хотя у нас нет полной ясности о природе аномальных участков рек іп строении долин, можно все же заключить, что приведенные сведения не противоречат данным повторной нивелировки. О поднятии земной коры косвенно свидетельствует также образование своеобразной широкой поймы $(2-4 \kappa м)$ со многими старицами у истоков р. Нарвы. Это связано, с одной стороны, с наличием Омутских порогов (аномальный участок с падением 44 cм/км) и, с другой стороны, именно с современным поднятием, благодаря которому ухудшается сток из озера. Перед порогами это ведет к более интенсивному меандрированию русла реки, а также к обширным наводнениям. Связано ли это с дифференциальными движениями земной коры по тектоническим нарушениям, общим перекосом земной поверхности в южном направлении или влиянием обоих факторов - пока не ясно. Самой вероятной является последняя возможность.

Қак явствует из данных Г. Желнина [5], в Южной Әстонии намечается общее, хотя и слабое, опускание со скоростью до 1,2 мм в год. Область наименьших падений рек совпадает с областью наибольшего опускания (рис. 4,6$)$. По сейсморазведочным данным, поверхность фундамента относительно быстро погружается в южном направлении у устья р. СуурЭмайыги и между Таэваскода и Хольванди, т. е. приблизительно там, где сгущаются изобазы, полученные повторной нивелировкой. Наиболее погруженная часть фундамента остается к востоку от линии Мехикоорма-Хольванди-Клийма-Петсери (Печоры), т. е. тоже примерно соответствует области наибольшего опускания. Конечно, это общее опускание в среднем и верхнем течении рек пока не оказывает существенного влияния на их эрозионно-аккумулятивную деятельность. Большее значение здесь имеют древний и гляциальный рельеф, а также литологический характер размываемых отложений.

Приведенный материал свидетельствует о том, что многие черты геологического строения долин Эстонии находятся в тесной зависимости от характера современных движений земной коры на территории республики. При этом необходимо отметить, что из-за кратковременности развития долин особенности их геологического строения и эрозионно-аккумулятивной деятельности (продольный профиль, глубина вреза и др.) отражают не только характер современных движений земной коры, но и все разнообразие геологического строения территории. Ввиду этого выявление влияния современных движений земной коры на эрозионно-аккумулятивную деятельность рек часто затруднительно. 


\section{Л И Т Е Р А Т У Р А}

1. Былинская Л. Н., М ещ еряков Ю. А., О связи градиентов скорости вертикальных тектонических движений земной поверхности с сейсмичностью на примере территории западной половины Европейской части СССР, Докл. АН СССР, 154, № 3, 1964.

2. Вахер Р. М., Пуура В. А., Эрисалу Э. К., О тектоническом строении северо-восточной Эстонии, Тр. Ин-та геол. АН ЭССР, 10, 1962.

3. Желнин Г. А., Изучение вертикальных движений земной коры в Эстонской ССР методом повторных нивелировок, В кн.: Матер. совещ. по вопр. неотект. движ. в Прибалтике, Тарту, 1960.

4. Желнин Г. А., Применение метода повторных нивелировок для изучения вертикальных дзижений земной коры на территории Эстонской ССР, В сб.: Современные движения земной коры, № 1, М., 1963.

5. Желнин Г. А., Точность и возможности метода повторного нивелирования, В сб.: Современные и новейшие движения земной коры в Прибалтике, Вильнюс, 1964 .

6. Каяк K., Геология долины реки Вяйке-Эмайыги, Уч. зап. Тартуск. гос. ун-та, № $75,1959$.

7. Ма азик В. Я., О связи современных вертикальных движений земной поверхности территории Эстонской ССР с геофизическими полями и фигурой геоида, В сб.: Современные и новейшие движения земной коры в Прибалтике, ВильHюс, 1964.

8. Мещеряков Ю. А., Филькин В. А., Опыт составления карты падения рек и ее тектонической интерпретации, В кн.: Вопросы применения картографических методов при географических исследованиях, М., 1960.

9. Меще р яков Ю. А., Задачи и методы геолого-геоморфологических исследований при изучении современных тектонических движений, В сб.: Современные тектонические движения и методы их изучения, М., 1961.

10. Меще ряков Ю. А., Молодые тектонические движения и эрозионно-аккумулятивные процессы северо-западной части Русской равнины, М., 1961

11. Мй̈дел А. М., Распределение падений рек Северной Эстонии, Тр. Ин-та геол. АН ЭССР, 12, 1963.

12. М и йдел А., О связи направлений речных долин с тектонической трещиноватостью на территории Эстонской ССР, Ежегодник Эстонск. Географич. об-ва, Таллин, 1965 (в печати).

13. Мийдел А. М., Р а ука с А. В., Литология аллювиальных отложений Северной Эстонии, В сб.: Литология и стратиграфия четвертичных отложений Эсто. нии, Таллин, 1965.

a4. $\mathrm{U}$ р в ику К. К., О неотектонических движениях в Эстонской ССР на основе геологических данных, В кн.: Матер. совещ. по вопр. неотект. движ. в Прибалтике, Тарту, 1960.

15. Uрвику K. К., Некоторые вопросы геоморфологии Эстонии (Геоморфологическая комиссия при ОГГИ АН СССР), М., 1960.

16. О р в и к у Л. Ф., Новые данные о геологии озера Выртсъярв, Тр. Ин-та геол. AH ЭСCP, 3, 1958.

17. Побул Э. А., О строении кристаллического фундамента по данным геофизики, Тр. Ин-та геол. АН ЭССР, 10, 1962.

18. II я н а K., О геологии Балтийского приледникового озера и крупных местных приледниковых озер на территории Эстонии, Автореф. дисс. канд. геол.-мин. н., Таллин, 1962.

19. Сетунская Л. Е., Опыт анализа продольных профилей рек в целях изучения тектонических движений, Изв. АН СССР, Сер. геогр., № 3, 1959.

20. Уттер Л. Р., Попытка геологической интерпретации схемы изобаз территории Эстонской ССР, В сб.: Современные и новейшие движения земной коры в Прибалтике, Вильнюс, 1964.

21. Gu d e 1 is V. K., Latest and recent vertical Earth crust movements and the morphol'gy of the sea-coast of the East Baltic area, Bull. geod., No. 62, 1961

22. H a ng E., L iblik T., L inkrus E., On the relations between Estonian valley terraces and lake and sea levels in the late-glacial and holocene periods, Tartu Riikliku Ulikooli toimetised, nr. 156, 1964.

23. If y y ӓ E., On the late-quaternary history of the Baltic Sea, Fennia, 89, No. 1, 1963.

24. K I a a m a n n E., Maavärinaist Eestis, Eesti Loodus, nr. 4, 1964.

25. Mieler A., Ein Beitrag zur Frage des Vorrückens des Peipus an der Embachmündung und auf der Peipusinsel Pirisaar in dem Zeitraum von 1682 bis 1900, Acta Univ. Tartu, A, 9, Nr. 2, 1926.

10 ENSV TA Toimetised F-1 66. 
26. M i i d e 1 A., Holotseensete orgude geoloogilise arenemise seaduspärasusi Põhja-Eestis, Тр. Ин-та геол. АН ЭССР, 7, 1961.

27. Orviku K., Eesti geoloogilisest arengust antropogeenis, II. Eesti Loodus, nr. 3, 1960.

28. $\mathrm{P}$ a a $\mathrm{rm}$ a $\mathrm{H}$., On the tectonic structure of the Finnish basement, especially in the light of geophysical maps, Fennia, 89, No. 1, 1963.

29. R a m s a y W., Niveauverschiebungen, eisgestaute Seen und Rezession des Inlandeises in Estland, Fennia, 52, No. 2, 1929.

30. S a u r mo M., The mode of the upheaval in Fennoscandia during late quaternary time, Fennia, 66, No. 2, 1939.

31. S a u r a mo M., Land uplift with hinge-lines in Fennoscandia, Suom. Tiedeak. Toim., Sarja A, III, Geol.-Geogr., No. 44, 1955.

32. $\mathrm{Z}$ he $\ln$ in G., Secular vertical crustal movements in the north-western part of the U.S.S.R. and their relation to similar movements in Finland, Bull. geod., No. 62, 1961.

33. $\mathrm{Z}$ he $1 \mathrm{n}$ in G. A., Some results on neotectonic movements of the earth's crust in the Estonian SSR obtained by the method of repeated levellings, Abhandl. Dtsch. Akad. Wiss. Berlin, Kl. Bergbau, Hüttenwesen und Montangeol., No. 2, 1962.

34. Z e $1 \mathrm{n} \mathrm{i} \mathrm{n,} \mathrm{G.} \mathrm{Maakoore} \mathrm{kerkimine} \mathrm{Eestis,} \mathrm{Eesti} \mathrm{Loodus,} \mathrm{nr.} \mathrm{5,} 1958$.

35. Tilts en E. Pärnujõgi ja tema veejõud, Sisevete Uurimise Andmed, VIII, Tallinn, 1526.

36. Ve 11 n e r A., Eesti hüdrograafia ülevaade, Sisevete Uurimise andmed, I, Tallinn, 1922.

Институт геологии

Академии наук Әстонской ССР

\section{Поступила в редакцию} 17/IV 1965

\section{A. $M I I D E L$}

\section{NUUDISAEGSETE MAAKOORE LIIKUMISTE JA JÕGEDE EROSIOONILIS-AKUMULATIIVSE TEGEVUSE SEOSEST EESTIS}

Eesti orgude geoloogiline ehitus kõneleb tihedast seosest jõgeđe erosioonilise ja akumulatiivse tegevuse ning maakoore nüüdisaegsete liikumiste vahel.

Põhja-Eesti orgude geoloogiline ehitus viitab makoore üldisele kerkimisele, mis ilmneb eriti selgelt jõgede alamjooksul esinevas intensiivses pōhjaerosioonis. Viimane nähtub ¡ôgede pikiprofiilist (joon. 1), anomaalsete lōikude levikust (joon. 6), orgude sageli V-kujulisest ristprofiilist (joon. 3), alluviaalsete setete paksusest (joon. 2). Jõgede kesk- ja ülemjooksul on maakoore kerkimise mõju orgude ehitusele väiksem, sest mõlemat eraldab üldisest erosioonibaasist kohalik erosioonibaas Põhja-Eesti paekalda näol.

Loodimise ja geoloogiliste andmete vastandamine Pärnu jõgikonna jõgede anomaalsete lõikude asendiga (joon. 4,6) tõendab esimeste najal esile tõstetud šarniiri olemasolu, mis kujutab endast arvatavasti plokkidena liikuvat tektoonilist vööndit. See vöönd on üldjoontes jälgitav ka jõgede anomaalsete lõikude regionaalses levikus kirde-edelasuunalise tsoonina. Pärnu jōe parempoolsete lisajōgede alamjooksul põhjustab maakoore nüüdisaegsete liikumiste kiiruse muutus nende jōgede põhjaerosiooni, vasakpoolsetel lisajōgedel - akumulatsiooni.

Lõuna-Eesti jōgede alamjooksul esinevad alluviaalsed setted suhteliselt suures paksuses (joon. 5), jõgedel on siin väike langus ja anomaalsed lõigud puuduvad (joon. 6). Need faktid viitavad jätkuvale üldisele maakoore suhtelisele vajumisele Lõuna-Eesti nende orgude alamvoolul, mis suubuvad Peipsi-Pihkva järve ja Vörtsjärve lõunaossa. LõunaEesti jõgede keskjooksul asuvate anomaalsete löikude teke on seotud peamiselt vana reljeefiga. 
A. MIIDEL

\section{ON THE CONNECTION OF CONTEMPORARY MOVEMENTS OF THE EARTH'S CRUST WITH THE EROSIONAL-ACCUMULATIVE ACTION OF RIVERS IN ESTONIA}

The geological structure of Estonian valleys testifies to a close connection between the erosional and accumulative action of rivers, and the contemporary movements of the Earth's critst.

The geological construction of North Estonian valleys points to a general uplift of the Earth's crust, which is particularly revealed in the intensive river-bed erosion occurring in the lower course of the rivers. This is to be observed in the longitudinal profile of the rivers (fig. 1), spreading of anomalous sections (fig. 6), frequency of V-shaped transverse profiles of valleys (fig. 3 ), and thickness of alluvial sediments (fig. 2). In the middle and upper courses of rivers the influence of the uplift of the Earth's crust upon the structure of the valleys is slighter since both of them are separated from the general base of erosion by a local erosional base - the North Estonian glint.

The comparison of levelling and geological data with the distribution of anomalous sections of the rivers of the Pärnu river basin (figs 4,6 ) proves the existence of a saddle bend represented by a crush zone which probably moves in the shape of blocks. This crush zone is generally traceable in the regional distribution of anomalous sections of rivers, representing a NE-SW-directed zone. In the lower course of the rightsided tributaries of the Pärnu river, the alternations of the velocity of the contemporary movements of the Earth's crust cause a river-bed erosion in the named region, whereas in the left-sided tributaries they call forth an accumulation.

The alluvial deposits of the lower courses of South Estonian rivers are of a relatively great thickness (fig. 5); the rivers here have a small gradient, and anomalous sections are missing (fig. 6). These facts point to a general relative sinking of the Earth's crust which keeps on in the lower courses of those rivers that flow into the Peipsi and Pihkva Lakes and into the south part of Lake Võrtsjärv. The formation of the anomalous sections in the middle courses of South Estonian rivers is mainly connected with the ancient relief. 